\title{
FINANCIAL STRUCTURE, BANK PERFORMANCE AND ECONOMIC GROWTH IN NIGERIA: AN EMPIRICAL INVESTIGATION
}

\author{
H. B. RIMAN, G. E. EDAME AND J. U. BASSEY
}

(Received 8, June 2007; Revision Accepted 3, July 2007)

\section{ABSTRACT}

This paper examines the impact of financial structure on levels of bank performance and stock market development in Nigeria. Using OLS technique of analysis and data from 1970-2004, our result revealed that financial structure, legal/regulatory regime and macroeconomic environment affect bank interest margin. A wide interest margin, as noticed in our model is an indication that banks and stock markets are still inefficient, uncompetitive, oligopolistic and underdeveloped in Nigeria. The study therefore emphasizes the urgent need for Central Bank to deal with the different macroeconomic conditions, deposits insurance regime, financial market conditions that posse as hindrances and rigidities in the financial system.

\section{INTRODUCTION}

The traditional role of banks consist basically, financial intermediation, provision of efficient payment system and also serves as a conduct for the transmission of monetary policies. The role of financial intermediaries in enhancing economic growth had been severally documented after the pioneering work of Goldsmith (1969). Goldsmith has shown that banks and stock markets tend to grow, become larger and well developed relative to country's national output. His evidence also suggested that non-bank financial intermediaries and stock markets frequently grow relative to the banks size and importance as the countries expand economically.

This therefore summarizes that financial structure the mixture of financial instruments, markets and intermediaries operating in an economy changes as the economies grow. Financial structure which is also the degree to which a country financial system is either market-based or bank-based or mixture of both, also determines the level and type of financial intermediation, through either influencing or not influencing competitiveness amongst banks. Countries with weak market structure are usually considered as uncompetitive and bank based, and by implication, underdeveloped. Consequently, countries with market based financial system are said to be developed, and enjoys faster economic growth following a competitive market system that reduced financial rigidities and inefficiencies. Empirical evidence from previous researchers had also suggested that financial intermediaries, stock markets and domestics economies become increasingly developed under a marketbased system than in a bank-based financial system. Evidence from Dermirguc-Kunt and Huizinga (2000) suggest that Nigeria has a bank-based financial system and by extension, an underdeveloped financial and stock market develooment. Nigeria's weak financial structure is also suggestive of a country whose banking system is encumbered with rigidities, inefficiency and poor regulatory regime that stomie economic growth.

This research to our knowledge is the first work that attempts to examine the structural relationship between financial structure and bank performance in Nigeria. This study therefore seeks to investigate whether financial structure influences the pace of economic growth and stock markets development in Nigeria. The research is also intended to investigate the role of financial structure in enhancing the interest rate spread of deposit money banks. It is however arguable whether a wide interest spread influenced by financial structure induces (in)efficiency in the banking system. Finally, the role of explicit deposits insurance in influencing bank performance, financial structure and stock markets development shall also be examined. To achieve the above objectives this research paper shall be divided into the following sections. Section one is the introductory section, while section two examines related literatures. Sections three presents the methodology of research, section four discussed the results and finally raises conclusion from the discussion.

\section{LITERATURE REVIEW}

The issue of financial structure and bank development has remained a central issue lately. It has been suggested that financial structure or market power facilitates fast growth of the economy, horizontal expansion of industries, evolution of new firms and access to external financing of investment. The impact of financial structure on bank profitability has attracted strong research interest starting from the late 1980's. Researcher interest has been motivated by the changing market structure of banks, particularly, in deveioping countries. Research interest in financial structure began with the pioneering work of Goldsmith in 1969. Goldsmith (1969) sought to evaluate whether financial structure influenced the pace of economic growth. His work documented the existence of positive correlation between financial structure and levels of economic activities in some selected 35 countries using data prior to 1964. However, his work was unable to provide much cross country evidence due to data limitations. Goldsmith's work has provoked a large body of argument regarding the superiority of bank-based financial system over market-based financial system. Gerschenkron (1962) noted that bank based financial system can induce firm to reveal information and pay debt better than atomistic markets. In doing so, banks become more efficient in financing industrial expansion than markets in under-developed economies. Rajan and Zingales (1999) also opined that bank-based financial system are usually unencumbered by regulatory and restrictions on their activities and thus can exploit economies of scales and scope in financing industrial growth. Stulz (2000) opined that by lowering information symmetry and transaction cost in a bankbased system the overall financial development can facilitate efficient flow of capital and equity, thus, influencing investment and growth. He emphasized that the level of financial sector development and regulatory policies also influence the effectiveness with which the financial system can channel funds to productive end-users.

Hagen and Dinger (2004) hold a contrary opinion different from Siulz (2000). He noted that despite powerful banks having easy access to cheap funds, probably due to their economies of scales, such funds are thereafter made available to new entrants' banks at high cost. This circumstances, widens the interest spread, stifle competitions in the market and retards economic growth. The market-based view faults the capital, allocative efficiency of bank-based

H. B. Riman, Department of Banking and Finance, University of Uyo

G. E. Edame, Institute of Public Policy and Administration, University of Calabar, Calabar- Nigeria.

J. U. Bassey, Department of Business Administration, Cross River University of Technology, Ogoja Campus. 
system in stimulating growth and development. Proponents of this view emphasized that powerful banks frequentiy stomie innovation by extracting information rate and protecting established firms (Hellwig 1991). Guzman (2000), Pengano and Jappeli (1993) also confirms the view that Oligopolistic and bank-based structure widens interest spread of banks, reduce competition among financial market participants, thereby retarding economic growth through mechanisms that distort resources allocation and capital accumulation. Cetorelli and Gambara (1999), also noted that competition in the banking sector promotes the growth of those industries that are more in need of external financing by facilitating credit access to firms, especially, new entrants. Atje and Jovanovie (1993) and Harris (1997) suggested that a market-based system enhances growth through provision of liquidity. This enables investment to be less risky, as well as ensuring that companies can have access to liquid equity issues. Levine (2002), Boyd and Smith (1998) noted that market based financial system reduces inherent inefficiencies usually associated with bank when countries are passing through different stages of development. This therefore, enhances economic development and growth.

Another dimension of argument was introduced into the discourse. This is the financial services view. This view argues that the bank-based versus market based debates was of littie importance. The primary or first order issue is the ability of the financial system to ameliorate information and transaction cost. Furthermore, according to Huybens and Smith (1999) banks and markets only act as complements in the provision of financial services. To further strengthen the financial view argument, Beck and Levine (2001) in their empirical analysis of industrial growth and capital allocation did not find any strong linkage between financial structure and bank performances in either bank or market-based financial system. They concluded that financials structure per se does not explain bank performance, but rather financial deveiopment and legal and regulatory environment are critical factors necessary for efficient allocation of capital that would ultimately stimulate growth in both banks and stocks markets. Demirguc-Kunt and Hinzinga (2000) empirical work on financial structure and bank profitability revealed that banks were bound to experience higher profit and wide interest margin in a financial system that is bank-based. They further posited that the relative development of banks was rather worsened by banks wide interest spread and other market determinants. Therefore, it was rather the level of banks and stock market development that translate into the differences in banking sector efficiency and not necessarily the nature of financial structure that so exist.

Buch and Mathisan (2003) in their empirical analysis of 'Ghanas' banking sector found the presence of a noncompetitive market structure in Ghanas' financial system. The reason for the uncompetitive behaviour of the market was attributed to the persistent domestic financing need by the government. Government domestic financing repressed banks efficient performance. Ghana's non-competitive behaviour was evident by the presence of wide interest margins and spread; which hitherto resulted in low lending ratios and high loan default. Ngugi (2000) also in their study of interest rate spread in Kenya found a widening interest spread post liberalization of the economy. This wide spread that ultimately depressed Kenya's economic environment was due to an attempt made by the banks to reduce the increasingiy credit risk, as reflected by large non performing loans. Afolabi et al (2003) in their empirical work on the determinant of interest rate spread in Nigerian observed that, the oligiopolistic structure of the banking industry in Nigeria has greatly worsened interest rate spread. Consequently, the noticeable wide interest spread which was basically due to high operating and transaction cost had impacted negatively on other sectors of the economy. The primary role of deregulation as noted by Caminal and Mututes (1997) was to improve efficiency among banks through increase competitiveness. Cihaks and Podpierra (2003) did not find any such evidence in Kenya's economy. According to them, reforms had left behind a weak infrastructure, problematic legal and institutional environment and weak credit culture in Uganda. Financial reforms in Nigeria was targeted at stimulating saving and investment (particularly in the private sectors) enhance competitiveness and efficiency in the banking industry (Afolabi et al 2003). It however remains debatable if the current financial structure had impacted positively on financial intermediaries by way of developing the banks and stock markets in Nigeria.

\section{THE DATA}

The data for this research were obtained variously from International Financial Statistics, Central Banks Statistical Bulletin and Annual Reports and Statements of Accounts of various issues for the period 1970-2004. Following the rigorous routine in sourcing for these data, and the problems of inconsistencies in data generation in developing economies, the result obtained from our regression analysis should be interpreted with caution.

\section{METHODOLOGY}

The study adopts the empirical model of Financial Structure and Bank Profitability proposed by Demirguc_Kunt and Huizinga (2000). However, the model would be adjusted to fit in other variables that are of specific interest in this study. Such variables include real gross domestic product, dummy variable for explicit deposit insurance and Bank interest spread. We therefore estimate the regression equation in the following functional form

Bankdev $=\beta_{0}+\beta_{1}$ struc $+\beta_{2}$ Rgdp $+\beta_{3}$ Mcap $+\beta_{4}$ Dummy Where;

All the variables would be determined in serni-logarithmic form Bankdev is a variable for bank performance measured as net interest margin/total asset. A high interest margin in an indication of inefficiency of the banking sector resulting from oligopolistic market

Struc is a variable that proxy as financial structure. It is measured as the ratio of total assets of all Deposits Money Banks/Gdp. This ratio reflects the overall banking development in the banking sector. Gilbert (1984) and Berger (1993) have also expressed that such measurement could also proxy for market power as well as bank (in) efficiency. Arestis (2004) also added that this measure for financial structure would account for total factor productivity of the economy

MCAP which proxy for overall stock market development is measured as the value of total market capitalization/Gdp

Rgdp measures the real gross domestic activity of the economy resulting from financial intermediation.

The dummy variable captures the relevance of deposit insurance in sterilizing banks and stock markets.

Deposit insurance equals one if an explicit deposit insurance regime exist during the respective years and zero if contrary. Furthermore, the study also had to control fore the impact of macroeconomic environment on bank performance. Variables like inflation, real interest rate, and real Gdp and growth rate were included in separate model for bank development. Real interest rate is constructed as the different between the yield rate of three months government bond and inflation rate. Real growth rate is set to measure cyclical effects on bank interest spread on the economy.

\section{STATISTICAL RESULT AND DISCUSSION}

\section{CORRELATION MATRIX}

Table one provides the correlation matrix result for the financial structure variables. The result indicates that, a negative correlation exists between market capitalization and bank development $(-0.56)$. Financial structure which measures the degree of market participation and concentration also had a negative correlation with bank performance (-0.36). Gross domestic activities had a low positive correlation with market capitalization, financial structure and bank performance $(0.22)$ $(0.03)$ and $(0.05)$ respectively. The positive complementarities between gross domestic product and these variables had been 
previously documented, even though their complementarity's effect here appears so weak. The result signifies that financial and non-bank financial intermediaries that are better at acquiring information, reducing information symmetry, managing risk, and reducing transaction cost would mobilize surplus savings and allocate capital more efficiently as the financial system develops and become proactive and competitive.

\section{MACROECNOMIC PERFORMANCE AND BANK DEVELOPMENT}

Table 2 presents, the result for the effect of some selected macroeconomic variables on bank development. The model had significant statistical criteria. The result reveals that inflation is estimated to highly and positively influence bank interest spread. This suggests that banks profit more given an inflationary environment, through obtaining higher earnıngs from floats, high transactions cost and possible delays in crediting customers transactions. A high transactions cost would lead to highor !abour ses! as shown by Hanson and Rocha (1986) and a higher banks branch per capital ratio. The significance of real interest rate is associated with the wide interest margin. This also could reflect tat demand deposit frequently pay zero or below market rate of interest. Real gross domestic products which were also significant demonstrated the importance of banks in promoting investment activities through credit allocation to private sectors. Banking development has a strong causal effect of positively influencing economic activities through a dynamic credit allocation policy

\section{FINANCIAL STRUCTURE AND BANK CHARACTERISTICS}

The result in table 3 presents the behavioural relationship between financial structure variable and bank development. Financial structure variable had an expected negative relationship with a magnitude of -0.358 . This value is observed to fall below the sample mean. This result according to Huizinga and Demirguc-Kunt (2004) and CBN Annual Report $(2000)$ confirmed that Nigeria financial structure was bank-based, oligopolistic and underdeveloped. Stock market capitalization magnitude of -0.385 was also observed to be below the sample mean, also implying an under-developed capital market in Nigeria. The non-linear relationship between market capitalization and bank performance implies that the wide interest spread reduces banks access to equity and debt financing in the capita market. The effect of banks reduced access to funds via increase interest rate spread is witnessed in the low magnitude of gross domestic investment. This result confirms Ogun and lyoha $(2005)$ proposition that a wellcapitalized stock market has the possibility of increasing economic activities in Nigeria. Deposit insurance has a positive coefficient and was also significant at 0.01 percent. This reveals that existence of explicit deposit insurance encourages banks to engage in risky lending strategies to increase the contingency payout from the deposit insurance agent. This moral hazard problem according to Huizinga and Dirmirguc-Kunt (1998:24) can lead bank creditors to demand a higher interest rate. Also for a given level of risk, banks can lead money out more expensively than they would have, to increase their profitability through a wide interest spread.

\section{CONCLUSION}

The study had examined the Nigeria financial structure and its consequent influence on banks and stock market development. The study therefore, concludes that financial structure is particularly important at lower level of economic development since it has shown to distort competition among the deposit money banks, widens bank interest spread and reduces market capitalization

The study also concludes that in an underdeveloped banking and capital market economy (such as one experienced in Nigeria), markets tend to be rife with resource - costly inefficiencies and less - than competitive pricing behaviour as suggested by the relative high interest margins. Thus greater bank development, which necessitates a low interest margin, would engineer competition, higher efficiency and lower profits among finarcial intermediaries. Our result after looking for macroeconomic development indicates that deposit insurance and stock market development, improve the availability of equity financing to firms and may increase their borrowing capacity, and by extension also improve economic growth of the country. Controlling macroeconomic environment will also have the positive impact of reducing economic velocity and enhance the full mobilization of savings and credit allocation to productive end-users.

\section{REFERENCES}

Afolabi, J. A; Ogunleye, R. and Bwala, S., 2003. Determinants of Interest Rate Spread in Nigeria: An Empirical Investigation. NDIC quaterly 13, March 4-9.

Aretis, P. Luintel, A. ad Lunitel, K. B., 2004. Does Financial Structure Matter? Levy Economic Institute Working Paper (399): January 231-243

Arje, R. Jovanonic, B., 1993. "Stock Market Development" European Economic Review 37: 632-640.

Beck, T. and Levine, R., 2001. "Industry Growth and Capital Allocation: Does having a Market or Bank-based System Matter?" World Bank Research Working Paper 2670.

Berger, Allen N, 1995. "The Profit-Structure Relationship in Banking-test of market power and efficient structure hypothesis". Journal of Money, Credit and Banking 27: 404-431.

Boyd, J H and Smith, B. D., 1998. "The evolution of debt and equity markets in economic development" Economic Theory 12: $519-560$.

C8N, 2004. Annual Report and Statement of Account

Cetorelli, N and Gambara, M., 2001. "Banking market structure, financial dependence and growth: international evidence from industry data" Journal of Finance 65, (2): April 617-48

Cinak, $M$ and Podpierra, R., 2005. "Bank behaviour in developing countries: Evidence from East Africa". IMF working paper MP/05/129.

Demirguc_Kunt, A. and Huizinga, H., 1999. "Determinant of Commercial Bank Interest Margin and Profitability: Some International Evidence" World Bank Review 13, (2):

Demirguc Kunt, A. and Huizinga, H., 2000. "Financial Structure and Bank Profitability" World Bank Economic Review 16: 2-14

Dinger, $V$. and Hegan, J., 2004. "Bank, Markets Liberalization, Market Structure and Profitability: The case of Vertical Non-Integrated Banking Industries". European Integration Studies, University of Bonn Mimeo pp 22-26

Gerschenkron, A. 1962. "Economic Backwardness, In Historical Perspective". A Book of Essay of Cambridge, Mass: Havard University Press.

Gilbert. R. A. 1984. "Banking Market Structure and Competition" Journal of Money, Credit and Banking 21: $427-436$ 
Goldsmith, R. 1969 "Financial Structure and Development New Haven", Yale University Hanson, James A anc' Rocha, R. (1986) "High Interest Rate, Spread and the Cost of Intermediation. Two Studies: Industry and Financial Series 18 World Bank. Pp 234-246.

Harris, R D.F, 1997 "Stock Market and Development: A Reassessment" European Economic Review 41: 120130

Hellwig, Martin, 1991. "Banking, Financial Intermediation and Corporate Finance" In A. Giovanni and C. Mayer (eds) European Financial Intermediation. Cambridge University Press. Cambridge pp 35-63.

Huybens, E and Smith, B., 1999. "Inflation, Financial Market and Long-run Real Activity; Journal of Monetary Economics 43: 283-315

Levine, R. Loayza, is. dilu Devik, T., 2000. "Finaneial Intermediation and Growth: Causality and Causes" Journal of Monetary Economics 46:31-56
Levine R, 2000 "Bank-based or Market-based Financial Systems which is better?" Journal of Financial Intermediation 11, (4): $398-428$

Ogun, T. B and lyoha, F. O., 2005. "The Nigerian Stock Market and Future Economic Activities" Union Digest 9. (1\& 2): June p. 41

Rajan. R. G. and Zingales, L., 1998. "Financial Dependence and Growth" American Economic Review. June, 4048

Stulz, Rene, M., 1999 "Financial Structure, Corporate Finance and Economic Growth" Mimeo. Ohio State University pp 212-362

World Bank, 2001. "Financial and Growth: Policy Choice in a Volatile World". World Bank Policy Research Report Washington DC. World Bank 
APPENDIX

Table 1: Correlation Matrix Resilt

\begin{tabular}{|l|l|l|l|l|l|}
\hline & MCAP & RGDP & STRUC & DUMMY & BANKDEV \\
\hline MCAP & 1.000000 & 0.220913 & 0.609742 & 0.526016 & -0.168716 \\
\hline RGDP & 0.220913 & 1.000000 & 0.035692 & 0.019758 & 0.061552 \\
\hline STRUC & 0.609742 & 0.035692 & 1.000000 & 0.782444 & -0.364751 \\
\hline DUMMY & 0.526016 & 0.019758 & 0.782444 & 1.000000 & -0.302372 \\
\hline BANKDEV & -0.168716 & 0.061552 & -0.364751 & -0.302372 & 1.000000 \\
\hline
\end{tabular}

Table 2: Macroeconomic Variables and Bank Performance

Dependent Variable: RANYKDEV

Method: Least Squares

Date: 06/17/06 Time: $14: 51$

Sample (adjusted): 19762004

Included observations: 28

Excluded observations: 1 after adjusting endpoints

\begin{tabular}{|l|l|l|l|l|}
\hline Variable & Coefficient & Std. Error & t-Statistic & Prob. \\
\hline C & -21.96081 & 5.105491 & -4.301410 & 0.0003 \\
\hline RGRAT & -0.004172 & 0.024846 & -0.167931 & 0.8681 \\
\hline RGDP & 1.887754 & 0.441013 & 4.280493 & 0.0003 \\
\hline INF & 2.609359 & 0.544864 & 4.789006 & 0.0001 \\
\hline RINT & 0.020846 & 0.013703 & 1.521243 & 0.1418 \\
\hline R-squared & 0.882112 & Mean dependent var & 1.467522 \\
\hline Adjusted R-squared & 0.509436 & S. D. dependent var & 0.616055 \\
\hline S. E. of Regression & 0.431487 & Akaike info criterion & 1.317273 \\
\hline Sum squared resid & 4.282159 & Schwarz criterion & 1.555166 \\
\hline Log likelihood & -13.44182 & F-statistic & 28.009673 \\
\hline Durbin-Watson stat & 1.663638 & Prob (F-statistic) & 0.000338 \\
\hline
\end{tabular}

Table 3: Financial Structure and Bank Characteristic

Dependent Variable: BANKDEV

Method: Least Squares

Date: 06/11/06 Time: $15: 55$

Sample: 19702004

Included observations: 34

Excluded observations: 1

\begin{tabular}{|l|l|l|l|l|}
\hline Variable & Coefficient & Std. Error & t-Statistic & Prob. \\
\hline C & -9.990286 & 1.488240 & -6.712819 & 0.0000 \\
\hline RGDP & 0.192641 & 0.160950 & 1.896897 & 0.0410 \\
\hline STRUC & -0.358398 & 0.128100 & -2.797803 & 0.0090 \\
\hline MCAP & -0.385468 & 0.111169 & -3.467392 & 0.0017 \\
\hline DUMMY & 1.396360 & 0.432511 & 3.228494 & 0.0031 \\
\hline R-squared & 0.781766 & Mean dependent var & -4.977716 \\
\hline Adjusted R-squared & 0.751665 & S. D. dependent var & 1.382179 \\
\hline S. E. of Regression & 0.688784 & Akaike info criterion & 2.227276 \\
\hline Sum squared resid & 13.75829 & Schwarz criterion & 2.451741 \\
\hline Log likelihood & -32.86369 & F-statistic & 25.97126 \\
\hline Durbin-Watson stat & 1.523204 & Prob (F-statistic) & 0.000000 \\
\hline
\end{tabular}

